\title{
Competence as an ideological representation of the railroad surrounding the United States: a historiography between 1859 and 1869
}

\author{
ALEXANDRE HOCHMANN BÉHAR ${ }^{1}$ \\ MARCOS GiLSON G. FEITOSA ${ }^{2}$ \\ ${ }^{1}$ Instituto Federal de Educação, Ciência e TeCnologia de Pernambuco (IFPE), Paulista - Pe, Brazil \\ 2 Universidade Federal de Pernambuco (UFPE) / Departamento de Ciências Administrativas, Recife - PE, BraziL
}

\begin{abstract}
The concept of competition needs better definition in the field of Organizational Studies (OS). Originating in Economics, different conceptions are identified in the theorizations in OS. From a critical perspective, such an occurrence may be associated with the ideological practices of control and exercise of power, as well as anachronisms. Thus, considering the socio-historical character of social cognition and the construction of discursive meaning, in addition to the modern organizational reference to the US railway company from the Civil War, our objective was to analyze ideological approaches to dimensions associated with competition in the US rail environment between 1859 and 1869 . Thus, supported by 128 journalistic documents, we use the Infinite Conceptual Puzzle method to propose meanings associated with competition in the railway environment by discursive agents of the press and railway managers. The analysis presented proposes the ideological use of the concept, guided by the changes caused by the conflict, as well as the interests of the actors involved.
\end{abstract}

Keywords: Historiography. Ideology. Competition. American Civil War. US railways.

\section{Competição enquanto representação ideológica no ambiente ferroviário estadunidense: uma historiografia entre 1859 e 1869}

\section{Resumo}

O conceito de competição carece de melhor definição no campo dos Estudos Organizacionais (EOs). Esse termo é originário da Economia e identificam-se concepções diversas de competição nas teorizações em EOs. A partir de uma perspectiva crítica, a competição pode associar-se a práticas ideológicas de controle e exercício de poder, além de anacronismos. Assim, considerando o caráter sócio-histórico da cognição social e a construção de sentido discursivo, além da referência organizacional moderna ao modelo de organização e gestão ferroviária comercial estadunidense a partir da Guerra de Secessão (1861-1865), este estudo teve por objetivo analisar aproximações ideológicas a dimensões relativas à competição no ambiente ferroviário estadunidense, entre os anos de 1859 e 1869 . Assim, apoiados em 128 documentos jornalísticos, adotamos o método do Quebra-Cabeças Conceitual Infinito para propor sentidos associados à competição no ambiente ferroviário por parte dos agentes discursivos da imprensa e dos gestores ferroviários. A análise propõe o uso ideológico do conceito, orientado pelas mudanças ocasionadas pelo conflito e pelos interesses dos atores envolvidos.

Palavras-chave: Historiografia. Ideologia. Competição. Guerra de Secessão. Ferrovias estadunidenses.

\section{Competencia como representación ideológica en el entorno ferroviario estadounidense: una historiografía de 1859 a 1869}

\section{Resumen}

El concepto de competencia necesita una mejor definición en el campo de los Estudios Organizacionales (EO). Esa expresión es originaria de la Economía y se identifican diferentes concepciones de competencia en las teorizaciones de los EO. Desde una perspectiva crítica, tal competencia puede asociarse con prácticas ideológicas de control y ejercicio del poder, además de anacronismos. Por lo tanto, considerando el carácter sociohistórico de la cognición social y la construcción de un significado discursivo, además de la referencia organizativa moderna al modelo de organización y gestión ferroviaria comercial estadounidense a partir de la guerra civil estadounidense, nuestro objetivo fue analizar los enfoques ideológicos de las dimensiones asociadas con la competencia en el entorno ferroviario estadounidense entre los años 1859 y 1869. Así, con el apoyo de 128 documentos periodísticos, utilizamos el método Infinite Conceptual Puzzle para proponer significados asociados con la competencia en el entorno ferroviario por parte de agentes discursivos de la prensa y los gerentes ferroviarios. El análisis presentado propone el uso ideológico del concepto, guiado por los cambios causados por el conflicto y por los intereses de los actores involucrados.

Palabras clave: Historiografía. Ideología. Competencia. Guerra de Secesión. Ferrovías estadunidenses. 


\section{INTRODUCTION}

Conceptual production in the field of Organizational Studies (OS) has historically presented the often inadequate incorporation of the theoretical constructions of different fields of study (RAMOS, 1983; MOURA, 2014). Supported by anachronisms (MATITZ and VIZEU, 2012; MOURA, 2014; BÉHAR, 2019), the reasons that lead to this may be associated with ideologies orientated by the manipulation of individual behavior, due to the interests of specific groups (TRAGTENBERG, 2005; BARRETO, 2014; SEIFERT and VIZEU, 2015; BÉHAR, 2019). Thus, considering the importance of the concept of competition in OS, and variations in the associated conceptions (BARNEY and HESTERLY, 2009), in this article we have analyzed perspectives related to competition, using a historical and discursive approach.

The perspective adopted in this study was that the construction of discursive meaning is shown to be influenced by socio-historical conditions, which direct interpretative possibilities of reality (FOUCAULT, 1999, 2008). In other words, each context shares a social cognition that orientates individual understanding (VAN DIJK, 1990, 2012). Faced with these issues, discursive products constitute practices to exercise power, for their maintenance or modification in society (FOUCAULT, 1999, 2008; VAN DIJK, 2012), presented as ideological configurations of a specific social group to manipulate others, for their own interests (VAN DIJK, 2006, 2012, 2015). Thus, we understand that interpretations associated with the concept of competition both stem from the context in which they are inserted and orientate individual interpretations and attitudes in society.

Based on these conceptions, we see competition as a concept that originates from Economics and is incorporated into various theoretical conceptions of Administration, without aspiring to any specific definition. In its original field, the idea of competition arises with the model of $18^{\text {th }}$ century bourgeois society (HOBSBAWM, 2014a, 2014b), particularly associated with the conceptions of the classical economics school of thought (SMITH, 1976; BACIC, 2011). Seen as a type of force of nature, the organizer of commercial relations, competition was considered one of the pillars of this new society (WEBER, 2006; BACIC, 2011), centered on the ideas of progress and human development, in opposition to the remnants of medieval society (HOBSBAWM, 2014c).

The context in which these dimensions on competition are developed is permeated by profound and far-reaching changes in European society. The emerging democratic and individualistic ideas, together with new conceptions of rationality and technique, inspired actions for the independence of the United States of America (USA) in 1776 (FERNANDES and MORAIS, 2004; KARNAL, 2004; WEBER, 2006; HOBSBAWM, 2014c). The adoption of new European ideas of society in its federal constitution is also presented from the perspective of a magnificent destination reserved for a new nation. This conception is also linked to territorial advance (e.g., the "March Westward") and economic/industrial progress (FERNANDES and MORAIS, 2004; KARNAL, 2004; AMEUR, 2013). In order to address these issues, the railways were of fundamental importance in the context of the $19^{\text {th }}$ century (CHANDLER, 1999; PERROW, 2002).

Put forward as "the first modern business enterprises" (CHANDLER, 1999, p. 81), the railroad managers' actions and use of the railways proved to be fundamental for the North's victory in the Civil War (1861-1865). This issue definitively raised the railways to a higher level both within, and outside of, US territory. Domestically, the railroads became the central axis of national development. The state and businessmen joined together to construct a line of great commercial and military impact, the First Transcontinental Railroad, between 1862 and 1869. During this period, the railroad companies were presented as a cutting-edge organizational model, considering the challenges and opportunities of the time, and expanding significantly. Therefore, both the organizational model and US commercial railroad management, and its military use, presented references for other nations, such as Germany and France (PERROW, 2002; WHITE, 2012; WOLMAR, 2012a, 2012b).

From our observations, this article aims to analyze the ideological conceptions of competition in the US railroad environment between the period shortly before the Civil War and construction of the first transcontinental railroad. The decision to access two years before the conflict stems from the search for a corpus not connected to the conflict, in order to identify the discursive variation. On account of the characteristics of our research objective, we chose to be guided by a historical perspective. Although it is relatively recent in Brazilian OS, the historical nature of analysis is linked to the premise that constructions of discursive meaning stem from specific socio-historical contexts, wishing to break the anachronistic nature of OS (PIERANTI, 2008; COSTA, BARROS and MARTINS, 2010; VIZEU, 2010; MATITZ and VIZEU, 2012).

As methodological guidance, we accessed the Infinite Conceptual Puzzle (BÉHAR and FEITOSA, 2019), using original documents from the period in question. This choice represents the intention of conducting a critical and reflexive analysis of ideological 
orientation in symbolic constructions, focused on a specific concept, from a wide range of socially shared discourses, and related to a limited historical context. As a limit for the research, we selected the American Railroad Journal, on account of its relevance and audience at the time (PERROW, 2002; WHITE, 2012; WOLMAR, 2012a, 2012b), indicating the possibility of representation and influence of the context under study. The corpus comprised 128 articles, selected in 574 editions of the journal, distributed over almost 13,000 pages.

The next sections detail the theoretical and methodological bases that guided this study. We will then present the impressions arising from the analysis and this is followed by research considerations, in addition to its limitations, and opportunities for further research.

\section{Discourse and power to represent what is real}

Throughout the $20^{\text {th }}$ century, studies related to discourse expanded their analytical focus, highlighting the pragmatic nature of communication. Expansion of the symbolic perspectives of discursive analysis is not limited to the field of linguistics. On the contrary, the social conception, coupled with interpretations of the discourse, is presented as a multidisciplinary field, linked to areas of knowledge, such as sociology, psychology, linguistics and philosophy, among others (MAINGUENEAU, 2008). Thus, the aspect to be highlighted with regards to the role of discourse in the representation of a position refers to a declaration, and its propositional nature. Therefore, we can speak of discursive practices shared between specific social groups, not only in sharing information but also validating what, who, and to whom one intends to communicate (FOUCAULT, 2008; MAINGUENEAU, 2008).

As a communicative model, discourse allows interpretations which are not limited to written texts, but provides broader assumptions, although linked to a specific socio-historical context (FOUCAULT, 2008). This issue is also investigated by Van Dijk (2006), since the author considers the role of the social construction of language fundamental in a socially shared meaning. Aligned with this issue, power relations between social groups interfere both in the construction of, and the maintenance or change to shared meanings (VAN DIJK, 2006; FOUCAULT, 2008). The critical conception of ideology proposed by Van Dijk $(2006,2015)$ is associated with this issue.

To the author, the ideologies, governed by the discourse-cognition-context axis are presented as models of structure and discursive organization dedicated to orientating social practices, through the control of individuals subjective mental models. As a practice to exercise power and manipulation, the subjective representation of reality through ideologies tends to polarize positions, prompting conflicts and disputes between the endogroup (group of individuals aligned to the ideology) and exogroup (VAN DIJK, 2015). In this condition, context and discourse prove to be fundamental in ideological establishment. With regards to context, the importance falls on the time limits associated to the social cognition model, and the communicational characteristics associated with discourse. Discourse is presented as a means through which ideologies are learned; in other words, formulated and disseminated among group members. In this respect, ideological discourse presents specific structural characteristics, indicated by discursive manipulation to polarize positions, especially orientated by

[...] positive topics about US (how tolerant, modern, advanced, pacific or intelligent WE are), negative topics about THEM (how intolerant, behind, and aggressive, etc. THEY are), and avoiding negative topics about US (for example, our racism, or our international aggression, or THEIR contribution to our economy and well-being) (VAN DIJK, 2015, p. 56).

Thus, Van Dijk $(2006,2015)$ understands that a social analysis of ideology presupposes not only a detailed discursive examination (discursive agent and structure), but detailed contextualization of the communicative environment (in its macro-and micro-sociological components), and a description of the constituent elements of shared social cognition during the period under analysis. These aspects are detailed in the following sections, including the methodological procedures.

\section{The economic conception of competition and the formation of US society}

With regards to economic perspective, competition is linked to the concept of perfect competition, and "a competitive company is one that has the capacity to compete, and this capacity stems from a set of skills and conditions developed by it, or is provided by the environment, and required to exercise competition" (CARPINTÉRO, 2000, p. 6). Responsible for the scientific dimension linked to competition, the classical economics school of thought "considers competition as an organizing force 
that is displayed in the market" (BACIC, 2011, p. 24), guided by an "invisible hand" (SMITH, 1976, p. 438). On this foundation, "economic and social progress results exclusively from individual initiative" (GASTALDI, 2005, p. 51). On this issue, Bacic (2011, p. 19) understands "competition as a basic phenomenon that directs and confers its distinct dynamic on the capitalist system".

The rise of this conception is not isolated to a social context. These considerations denote a way of challenging the medieval model, and the rise of the bourgeoisie in the $18^{\text {th }}$ century. The reinforcement of new conceptions of rationality, individual freedom and justice are linked to this period, clearly represented by the French and Industrial Revolutions (WEBER, 2006; HOBSBAWM, 2014c).

Fundamental for the establishment of this new society, the French Revolution was presented as a political wing, aiming to break traditional state structures from the premises of rationality, freedom and justice (HOBSBAWM, 2014c). Another milestone of this period, the Industrial Revolution, facilitated the development of a new economic model of production, sustained by new conceptions of rationality and technique (WEBER, 2009; HOBSBAWM, 2014c). Linked to the illuminating ideas of rationality, progress and development, industrialization did not limit the consequences to the economy, but related them to demonstrating the level of social evolution (DOBB, 2012; HOBSBAWM, 2014c).

The unfolding of these events was closely followed by the thirteen British colonies in North America, which had shown to be a major colonizing boost since the $17^{\text {th }}$ century, although heterogeneously. With regards to this, Karnal (2004) observes that while the northern colonies presented similar weather to that of its metropolis, which fostered the development of a diverse agricultural production, to supply the domestic market, the weather in the southern colonies favored the establishment of monoculture production for export, on estates using slave labor. Thus, northern ideas developed independently, and in opposition to the British crown`s attempts to control the colonial territory. This mobilization led to the country`s declaration of independence in 1776 (KARNAL, 2004; AMEUR, 2013).

Although these differences prevented a better national constitution, "the country, as a whole, remained faithful to the vision it had constructed of itself: an independent, democratic and self-sufficient place, guided by well-intentioned people who marched towards progress" (FERNANDES and MORAES, 2004, position 1.634 of 4.675). Between 1790 and 1860 (AMEUR, 2013), this idea of greatness is identified in territorial (from 2 million $\mathrm{km}^{2}$ to 8 million $\mathrm{km}^{2}$ ) and population growth (from 4 million inhabitants to 31.5 million inhabitants).

However, as the nation became stronger, the structural differences between the North and South clashed, and plans to become a major world power were compromised. The spark for national dissolution took place with Abraham Lincoln's victory in the 1860 elections, placing the two models of society head to head, in a domestic battle (AMEUR, 2013). The consequences of the Civil War were not limited to changes in the political, institutional and social setting of the US nation, they were related to the establishment of the railroad organization, as a means to promote the ideas of progress and development. This aspect is detailed in the next section.

\section{The rise of railroad organizations and the Civil War}

As observed, the development of organizations and the US railroad network were placed in the constitution of this nation's bases, from new, shared social principles in Europe. Thus, the overall dimension associated with the model reflects the beliefs in organizations to promote social and technological progress, resulting from liberal economic practices. These aspects are associated with democratic ideas of individual freedom and justice, supported in the new conception of rationality (WEBER, 2006; HOBSBAWM, 2014b). Linked to this reality are specific characteristics of US society: a) the commercial nature, supported on the bases of what would be configured in capitalism; b) the population's ethnic, religious and cultural diversity; c) development of a domestic market disconnected from the metropolis, on account of the British crown's disinterest in establishing a colonizing process; and d) its expansionist nature (FERNANDES and MORAIS, 2004; KARNAL, 2004; AMEUR, 2013).

In this setting, the railways were seen as a path towards progress and the technological, economic and social impacts resulting from its operations largely shaped the constitution of the US nation. This conception does not only refer to the establishment of the above-mentioned organizational model but, also, the impacts provided by the railway expansion in a wide range of productive activities, and the various cities and isolated societies served by its routes which gained a rapid connection with the rest of the country (CHANDLER, 1963, 1999; PERROW, 2002). 
However, although the first locomotives had started to cross US territory in 1828 (WOLMAR, 2012a), it was from the 1850s that the railways reached the levels of growth and operational complexity that required the application of new administrative technologies (CHANDLER, 1963). The development of these practices would play a fundamental role in the North's victory in the Civil War, and this conflict was crucial for the development of these organizations and their managerial model (CHANDLER, 1963; PERROW, 2002; WHITE, 2012; WOLMAR, 2012a, 2012b).

Although the perspective related to the presence of the railways was indicative of development, structuring of the US railway environment was guided by competitive practices that adopted various approaches. Since the establishment of railway companies was market-orientated (unlike England, where the possibility of commercial operations required state authorization), the development of the US railway network was governed by intense and even aggressive disputes. Thus, corrupt practices were not uncommon for the concession of benefits from local political representatives, and to sabotage competitors ' railway lines. This condition remained until the Civil War, even with the proximity between the railway companies and military organizations (Perrow, 2002; White, 2012; Wolmar, 2012a, 2012b).

In addition to representing the dispute between the different socio-economic models practiced on US territory, the Civil War is presented as the first military conflict to rely on weapons and technologies originating from the Industrial Revolution. Thus, the northern states use of the railways maximized the impact of military innovations, providing greater flexibility to military operations and their capacity to transport supplies and troops. Nevertheless, the northern army relied on the important presence of railway executives at the command of the northern troops and, in the leaders ' point of view, they were equipped to provide efficient transport management (Wolmar, 2012a, 2012b).

The identification of military potential, associated with the railroads, transformed the way that the state interacted with these organizations. Thus, from May 1862, with the signature of the Presidential Act that authorized the construction of the United States ' first transcontinental railway, the central government's role began to boost and reinforce the national railway sector. With regards to this change, Perrow (2002), White (2012) and Wolmar (2012a) observe the government's investment of large financial sums in the railroad expansion, the establishment of large corporations, which reached over a large part of the national territory, transporting volumes much higher than those practiced in the pre-war period, in addition to the concentration of power, with the imposition of organizational demands with the state. Thus, Wolmar (2012b, position 1.135 of 6.838) observes that "generally speaking, the war secured a vital position in national infrastructure for the railroads."

Following these transformations, competition between railway companies also reached new heights. Although, prior to the conflict, competition was restricted to the local or regional dimension (PERROW, 2002; WHITE, 2012; WOLMAR, 2012a, 2012b), following the conflict, competition became a national, or at least inter-regional dispute, intensifying the above-mentioned corrupt practices, focused on preventing competition (PERROW, 2002; WHITE, 2012). In this new condition, the railway companies started to have their practices questioned. The perspective shared between a part of the population is that these businessmen were acting in a dishonest, manipulative and self-centered way (Wolmar, 2012a; White, 2012). In so far as dependence on railway transport increased in US society, new questions emerged about these practices, although the actions focused on change were limited (Wolmar, 2012a).

Following this socio-historical contextualization of the period, the next section details the methodological procedures adopted for the research.

\section{METHODOLOGICAL PROCEDURES}

Considering the characteristics of this study, we guided our research using a historical perspective, a dimension that has become more prominent in the field of OS, particularly studies which focus on questioning the mainstream. This perspective is in opposition to what is seen as the ahistorical and deterministic nature of some OS approaches. The relevance of a historical analysis is placed not only a way of forming scenarios from the past but, also, (and, particularly), allows new interpretations of current-day problems (VIZEU, 2010; COSTA, BARROS and MARTINS, 2010).

Thus, construction of the corpus occurred with public documents which were shared at the time. Therefore, we accessed articles in a journal identified as a leading forum within the setting of US railroad activity during the $19^{\text {th }}$ century: the American Railroad Journal (PERROW, 2002; WHITE, 2012; WOLMAR, 2012a, 2012b). We identified 163 journalistic articles related to 
railway competition in this journal, between 1859 and 1869, forming a total of 574 editions of this publication and 12,938 pages. Since only the representatives of railroad companies and the press presented a volume and continuity of publications among the social actors identified in the analysis, our analysis focused on 128 journalistic articles related to these actors.

As the analytical procedure, we supported our research on the Infinite Conceptual Puzzle method proposed by Béhar and Feitosa (2019), from Koselleck`s (1992, 2006) Conceptual History, and Van Dijk`s (2006, 2012) Critical Discourse Analysis (CDA). Thus, a synchronous analysis of a concept is proposed, highlighting the social context to which it is linked (based on the premises of Conceptual History), focused on a critical-reflexive analysis of the ideologies present in the discursive considering relations between the individual, context and discourse (based on the premises of CDA) - and focused on the analysis of multiple discourses inserted in the same contextual cross-section (BÉHAR and FEITOSA, 2019). Thus, they are the premises of the Infinite Conceptual Puzzle: the direction of the investigation towards a synchronous discursive analysis of a specific concept; analysis using public or private documents; the documents represent a multiplicity of discourses, being discourses that presuppose shared, and historically dated, socially subjective constructions; subjective constructions that interfere in the interpretation, and consequent individual action; interpretation and action marked by power relations that sustain a particular social structure and a social structure identifiable through the discursive route.

Lastly, we observed that the analysis presented in the next section, was operationalized through a lexical analysis of the discourses, as proposed by Van Dijk (2006). Thus, we guided the investigation by the variation in the lexical elements in the discourse. As a premise, we set off from the consideration that lexical choice is presented as a relevant means for ideological expression in the discourse. Thus, this discursive analysis is focused on the factors of preposition (adjectives, complements and sentence structure), local and global coherence (construction of semantic coherence in the discursive context) and propositional relations (a search for what is beyond the written word) in argumentative support, in a specific discourse (VAN DIJK, 2006). Therefore, our focus was to carry out these stages of the discursive analysis related to the conceptions of competition in the discourse in which this concept is inserted.

\section{Discursive analysis on the conceptions of competition}

As observed, conducting the analysis proposed resulted in the identification of the social actors who most consistently positioned themselves on railway competition in the corpus in question: a) railroad company representatives (72 articles); and b) representatives of the press (56 articles). For representatives of the press, we wanted to refer to journalistic articles in the American Railroad Journal, or were reproduced in the journal under analysis, without any individual authorship in other publications. Thus, the selection of journal content is referenced in Perrow (2002), White (2012) and Wolmar (2012a, 2012b), who highlight its relevance and audience at the time. With a total of 128 journalistic articles, we will continue to present the analysis focused on our cross-section by social actor, and then organized chronologically.

From the railroad managers ' perspective, the idea of competition in the railroad environment changes very little in the period under analysis. Generally speaking, the managers highlight competition as something negative, which needs to be avoided, which is seen by Béhar (2018) as a negative perspective of competition. In other words, this means that, according to the railroad managers, competition is seen as negative for support, business expansion and even the survival of their companies. In this respect, although it differs from the idea of shared economy at the time, competition, in the period prior to the Civil War, is presented with adjectives such as "ruinous", "impolitic", "aggressive", "vigorous", "disastrous" and "evil."

The representation of this perspective could be expanded by observing the support for agreements on the value of taxes and the desire to limit competition (especially with regards to the entry of new companies on sections considered saturated) in other sections. Therefore, these representatives` shared understanding was to combat competition, as a way of preventing the evils associated with it.

However, during the period in which the Civil War unfolds, although the perspective related to competition remains aligned with a negative idea, we observe some alterations in the argumentative orientation. In this regard, we highlight a higher volume of publications related to encouraging commercial agreements and the merger of railroad companies, as a means of avoiding competition. The relevance of mergers and agreements is specifically detailed in two articles published between April and May 1863. In one of these, a convention held between railroad company managers is featured, with the objective of establishing common regulations to be followed by members with regards to charging transportation taxes. The second article 
refers to the Consolidation Law, and is commented on by railroad managers. Premises and positive aspects are presented on the law, from the point of view of protection against competition, indicating this "need."

As highlighted, we did not observe any substantial alterations in the perspective of competition shared by railroad company representatives during the period between the end of the domestic conflict and the construction of the first US transcontinental railroad. Generally speaking, for almost 4 years after the Civil War, a negative dimension of competition remained unchanged between company representatives, guided by the idea that this would cause severe financial losses, and must be avoided via alternative routes, and the acquisition of other companies but, mainly through commercial agreements.

However, although with less representativity, representations of a new conception of competition can be identified among railroad managers. Between 1868 and 1869, we observe arguments with alternatives for dealing with railroad competition, such as changes to the times and stops, an increase in the level of passenger comfort, improvements associated with customer service, a reduction in the price of supplies, and even a search for increased efficiency in cost management, to deal with fare reductions, resulting from competition. Béhar (2018) calls this conception a negative perspective of positive consequences. In this respect, it is shown to be underlying the idea that competition, in a certain sense, is something inevitable, which the managers need to tackle. However, a negative conception of competition remains, resulting from the premise that its existence involves a financial loss, an increase in management complexity, and restrictions to managers and organizational actions.

Associated with these arguments, we share the perspective that the railroad managers ' negative conception of competition stems from the interest in guaranteeing privileged access to markets, providing a higher financial income and, possibly, higher profitability. In relation to the contextual aspects, we see an approach towards the classical perspective of competition, although from a conception in opposition to its occurrence, and even its inevitability (particularly at the end of the period under analysis). Inevitably, we put forward the idea of competition as a natural force, resulting in gains for society, from individual initiatives (SMITH, 1976; GASTALDI, 2005; BACIC, 2011).

Considering these points, we share the idea that the components of the ideological structure proposed by Van Dijk (2015), are present in the railroad managers ' discursive construction. Reinforced by the context of the time, these components are configured by the criticism of competition, associated with the various evils of entrepreneurial action. In this respect, we highlight discursive polarization, focusing the criticisms on competitive practices (and those responsible) on the exogroup, or the "group" to be fought. Underlying what could be considered discursive manipulation is the interests of these managers and their organizations.

With regards to the representatives of the press, we observe a significant alteration in the conceptions shared on railroad competition during the period under analysis. In the first instance, in the period prior to the conflict, actors of the press link competition to what Béhar (2018) calls the positive perspective of competition. The author refers to the idea that (free) competition brings about benefits to society, through a fair market balance. Referring to the classical economics perspective, the ideas of what competition presents as a "natural selection" among organizations are also shared by these actors, with success as an outcome of good management capacity. In this position, criticisms of actions to combat competition by railroad managers are also presented, seen as a way to promote illegal acts and corruption. In this perspective, for representatives of the press, the state should act as the defender of competitive freedom, which brings about socially shared gains, against the railroad managers` position.

Also, from this perspective, we observe representatives of the press questioning the criticism of competition, made by railroad company managers. In the section analyzed, arguments are presented that justify the downturn in railway transportation in 1857 , in opposition to the railroad managers arguments that the crisis had been caused by excessive number of competing railroads. In this crisis, the representatives of the press highlight the downturn in agricultural production and the consequent reduction in traffic. This agent also presents a successful case caused by tackling free competition, highlighted by individual effort. Capacity, perseverance and popular support of the emerging railroad company are highlighted in this article. From a shared interpretation, our understanding is that this perspective of competition is in line with the ideas present in the constitution and consolidation of the US nation, as Fernandes and Morais (2004) and Ameur (2013) observe. This idea is also in line with liberal economic practices, put forward at the time as adequate, to allow human and technological development, governed by economic growth (WEBER, 2006; HOBSBAWM, 2014b). In Van Dijk's (2015) ideological conception, our understanding is that the first impressions presented by agents of the press were adequately aligned with the occurrences of the macro-social context, which were ideological constructions related to competition during the period (SMITH, 1976; BACIC, 2011). In this 
understanding the railroad managers symbolized the opponents of the perspective of social advancement, and expansion of the common good, the consequences of competition from the perspective of classical economics.

However, this argumentative setting is transformed by the evolution of armed conflict and authorization to construct the first US transcontinental railroad (remaining this way until the cut-off date for this research - 1869). Thus, from August 1862, we observe a position from the press opposing free competition between the railroads, taking on a negative perspective of competition. Adjectives such as the "evils (of competition)" start to be associated to this, as well as the establishment of relationships between competition and railroads as a cause for these organizations' unfavorable results in 1862. Over the years under analysis, representatives of the press started to call competition, "ruinous", "evil", "unfavorable," "reckless" and "detrimental."

Associated with the railroad companies' negative results, competition between the US railways should be avoided and fought, while "profits" could have arisen at these companies through routes in which there was no established competition. The Civil War is also put forward in the discourse of the press as a favorable way to avoid competition between railroad companies, via increased receipts.

Another aspect to be observed and intensely reinforced is related to the press correspondents` defense of agreements, partnerships, mergers and acquisitions between railroad companies, in order to avoid competition via rate controls. These actions, highlighted as an "absolute need" and "shrewd" and "prudent", allowed the establishment of a "giant corporation" to face international competition.

With regards to this dimension beyond national borders, a new conception of competition shared between press agents can also be observed: the positive perspective of competition (BÉHAR, 2018). This is configured as a perspective of railroad competition focused on the external market, as a means for geopolitical affirmation with other nations. The argumentative construction that this conception intended to confirm the nation's right to compete internationally with other industrialized nations, with the goal of achieving a new level of civilization, development and progress. Of paramount importance, actions for competition should not only be governed by commercial, but also military practice, and the railroads were the means for this (BÉHAR, 2018).

In this regard, we highlight the vision presented in a journalistic article in 1862, that the city of San Francisco would become one of the "largest and most flourishing in the world", on account of the competitive absence of other large urban centers on the Pacific coast, similar to New York or Liverpool. The means for this achievement was related to the completion of the transcontinental railroad. Thus, the extensive US railroad network is presented in a patriotic way, and as a representation of strength, progress and union with other nations.

However, in the period between the end of the Civil War and completion of the Pacific Railroad, the positive perspective of competition becomes more frequent. In this respect, at various times it is linked to the transcontinental railroad project, and an idea of competition that transcends national limits is highlighted. Governed by the liberal principles of classical economics, the possibility of US "supremacy" over other nations also stems from the possibility of the railroad companies accumulating wealth domestically, through agreements and monopolies. The positive perspective of competition gains expansionist and imperialist dimensions, observed in statements such as the section that criticizes the absence of "a foreign market to call our own" or even the possibility of "growth of a magnificent Empire in the Pacific."

From these issues, we highlight the coexistence of two perspectives related to railroad competition, shared between members of the press, from the period in which armed conflict unfolds. Far from being placed as contradictory, they appear to present complementary points of view. In other words, considering the possibility to compete politically and economically on an international level, resulting from the railroad expansion, the extreme competition practiced domestically would cause the companies to become weak and make it impossible to achieve this "higher level." Thus, our reading indicates the idea that this objective could only be reached by strengthening US railroad companies, preparing them to compete beyond national territory. Essentially, this reinforcement would stem from a decrease in domestic competition.

In our understanding, the representation of the ideological conception of competition presented by members of the press transforms from the unfolding of the Civil War. With the expectation of competing globally, the railroad managers, the former "enemies" (exogroup), start to be perceived as partners (focus on the endogroup), in the dispute with other nations (new exogroup). Underlying the discursive construction, we associate the representative nature of progress and national 
development, resulting from the nation's competitive capacity. These are presented as the fundamental characteristics of the new economic model (DOBB, 2012; HOBSBAWM, 2014c), rising in Europe since the $18^{\text {th }}$ century (HOBSBAWM, 2014c), and one of the foundations of US society (FERNANDES and MORAES, 2004; KARNAL, 2004; AMEUR, 2013). In this context, the railroads were seen as one of the main social demonstrations of a nation's progressive and development capacity (CHANDLER, 1999; PERROW, 2002; WHITE, 2012; WOLMAR, 2012a, 2012b). In these aspects, we interpret the patriotic discursive constructions by representatives of the press analyzed, with the railroad as the means for US society to achieve this higher level. To this construction, we associate an example of the micro-sociological component, with the objective of bringing about macro-sociological consequences (VAN DIJK, 2015), through the exercise of media power. However, we were not able to analyze the impact of these discursive productions on the macro-social context.

From the analyses presented, we have investigated the interpretations related to the conceptions of competition during the period under analysis, also considering an appreciation of ideological indications in discursive construction. With regards to these points, it also appears possible to associate the analysis with another relevant aspect of Van Dijk's (2015) theory of ideology: sharing ideological values between specific social groups or, with reference to the author, the products of social cognition. Having highlighted these issues, the following section presents the final considerations of this study.

\section{FINAL CONSIDERATIONS}

The aim of this study was to analyze the ideological conceptions of competition in the US railroad environment during the Civil War, and construction of the first transcontinental railroad between 1859 and 1869. This proposition took place from central issues, such as: a) the relevance of US railroads in the constitution of the contemporary organizational model, especially since the Civil War; b) the role of railroads as a symbol of modernity, progress and development in 19th century Western societies (CHANDLER, 1999; PERROW, 2002; WOLMAR, 2012a, 2012b; WHITE, 2012); c) the influence of the ideas of justice, freedom and individual action, resulting from the rise of the bourgeoisie in Europe, with competition as the central aspect of the new model of society (SMITH, 1976; WEBER, 2006; BACIC, 2011; HobsbawM, 2014a, 2014b, 2014c); d) the specific characteristics of establishing US society, from a linked historical context, highlighted in the previous item (KARNAL, 2004; FERNANDES and MORAIS, 2004); d) weakness in the conceptual drafting of OS, marked by anachronisms and ideologically orientated constructions (RAMOS, 1983; TRAGTENBERG, 2005; MATITZ and VIZEU, 2012; BARRETO, 2014; MOURA, 2014; SEIFERT and VIZEU, 2015; BÉHAR, 2019).

Linked to the last aspect, we share the perspective that discursive constructions are influenced by socio-historical conditions, which adhere to subjective perspectives of reality, supported by power relations (Foucault, 1999, 2008; VAN DIJK, 1990, 2012). In the search for the exercise of power are ideologies sustained by the discourse-cognition-context axis (VAN DIJK, 2006, 2012, 2015). Thus, by conducting a historical analysis (Pierantl, 2008; Vizeu, 2010; COSTA, BARROS and MARTINS, 2010), we highlight the possibility of investigating the concept over time, inserted in specific social contexts, and endowed with specific meanings. Therefore, through use of the Infinite Conceptual Puzzle (BÉHAR and FEITOSA, 2019), in addition to the historical nature of the analysis, we analyzed the discursive constructions of multiple actors, in relation to the social context. By forming the corpus, with 128 journalistic articles from the American Railroad Journal, we then conducted a lexical analysis (VAN DIJK, 2006).

With regards to the interpretations resulting from the analysis, divided between the discourse of the railroad company representatives and those from the press, a differentiated understanding can be created, which presents a variation from the associated historical context. Related to the discourse that the railroad company representatives presented, we highlight a slight variation during the period of analysis. The majority associate competition between railroads as something harmful to business and that, therefore, should be contained through agreements, mergers and acquisition. The point of view shared by these social actors differs from what can be understood as the liberal cultural bases of the US nation (Fernandes and Morais, 2004; Ameur, 2013). The representation of this ideological conception lies in identifying the competition as an exogroup, which should be combated, in order to avoid greater problems. We associate the entrepreneurial gains resulting from the lack of competition to this, particularly with regards to the increase in financial profit.

In a different manner, we observe the transformation of the perspective of railroad competition by the press during the period under analysis. Starting with a positive perspective of competition in the period prior to the conflict (in which free competition acts to improve the overall efficiency of the market, with gains for all of society), the overall shared vision between these social 
actors alters, with the battle unfolding, and approval of the first US transcontinental railroad. Domestic competition between US railroad companies appears to be linked to the negative perspective of competition, while the possibility of competing internationally through these railroads is pronounced, receiving the positive title of competition. Thus, we observed that the conceptions presented throughout the analysis are in line not only with the railroad companies 'interests, but also (and, perhaps, especially) those of the state. However, these interests appear to vary both in line with the premises of classical economics - the perspective that the gains could be shared with all of US society, while the risks inherent to this "force of nature" are minimized (GASTALDI, 2005; CARPINTÉRO, 2000; BACIC, 2011) - and the shared point of view in the international context in question - international disputes, inserted in an environment of colonial expansion between industrial nations, in the search for supremacy (DOBB, 2012; HOBSBAWM, 2014c).

To the discursive products observed between representatives of the press, we associate ideological characteristics as diverse as the argumentative constructions related to competition. Therefore, in the period prior to the military conflict, the ideological conception of competition presented by representatives of the press were positioned in line with macro-social discursive constructions (particularly those related to the classical economists` idea of competition), directing criticism to the railroad managers (exogroup), in opposition to free competition. However, shortly after the start of the military conflict, a profound change takes place in the perspective of competition shared by this agent. From this time on, the railroad managers are seen as a part of the endogroup (in an attempt to avoid internal competition between railroad companies), with the other nations that compete for international trade in the exogroup. Linked to these issues, our understanding is a search for the influence of public opinion (macro-social), from a patriotic discourse (micro-social).

However, our intention was not to present a definitive analysis. Thus, with regards to the limitations of this study, we highlight not only the historical nature of this research conducted in a time and culture that is very distant from the occurrences under analysis, but also the restricted use of the document source, which far from representing a generalized point of view, represents interpretations of a specific and dated social cross-section. To these we add the limitations inherent to an interpretivist study, which assumes a level of interference from the researcher in the analysis. Therefore, we would like to invite the academic community to contribute with the research and development of perspectives historically guided by the concept of competition in the organizational domain. With regards to this issue, we hope to put forward new possibilities for preparing the concept and associated practices, in order to contribute towards the transformation of the reality(ies). 


\section{REFERENCES}

AMEUR, F. Guerra de Secessão. Porto Alegre: L\&PM, 2013.

BACIC, M. J. Gestão de custos: uma abordagem sob o enfoque do processo competitivo e da estratégia empresarial. Curitiba: Juruá, 2011.

BARNEY, J. B.; HESTERLY, W. Economia das organizações: entendendo a relação entre as organizações e a análise econômica. In: HARDY, C.; CLEGG, S. R.; NORD, W. R. (Org.). Handbook de estudos organizacionais. São Paulo: Atlas, 2009. v. 3, pp. 131-179.

BARRETO, T. F. Ética ou ideologia empresarial? In: ROCHA, H.; CASTRO, R.; VIZEU, A. (Org.). Comunicação e ideologia. Recife: Ed. UFPE, 2014. pp. 285-312.

BÉHAR, A. H. Competição organizacional enquanto representação de uma ideologia bélico-militar: o papel da Guerra de Secessão e das ferrovias estadunidenses na construção de um significado. Recife: Ed. UFPE, 2018.

BÉHAR, A. H. Meritocracia enquanto ferramenta da ideologia gerencialista na captura da subjetividade e individualização das relações de trabalho: uma reflexão crítica. Organizações \& Sociedade, v. 26, n. 89, pp. 249-268, 2019.

BÉHAR, A. H.; FEITOSA, M. G. G. Contexto histórico, discurso e ideologia na (re)elaboração de conceitos em estudos organizacionais: o método Quebra-Cabeças Conceitual Infinito. In: CONGRESSO BRASILEIRO DE ESTUDOS ORGANIZACIONAIS, 6., 2019, Recife. Anais... Recife: UFPE, 2019.

CARPINTÉRO, J. N. C. Novas técnicas e velhos princípios: competitividade empresarial e formas de gestão. Campinas, SP: Unicamp, 2000.

CHANDLER, A. Strategy and structure: chapters in the history of the industrial enterprise. Cambridge, MA: The MIT Press, 1963.

CHANDLER, A. The visible hand: the managerial revolution in American business. Cambridge, MA/London: The Belknap Press, 1999.

COSTA, A. S. M.; BARROS, D. F.; MARTINS, P. E. M. Perspectiva histórica em administração: novos objetos, novos problemas, novas abordagens. Revista de Administração de Empresas, v. 50, n. 3 , pp. 288-299, 2010.

DOBB, M. A evolução do capitalismo. Rio de Janeiro: LTC, 2012.

FERNANDES, L. E.; MORAIS, M. V. Os EUA no século XIX. In: KARNAL, L. et al. História dos Estados Unidos: das origens ao século XXI. São Paulo: Contexto, 2004. e-book.

FOUCAULT, M. As palavras e as coisas. São Paulo: Martins Fontes, 1999.

FOUCAULT, M. A arqueologia do saber. Rio de Janeiro: Forense Universitária, 2008.

GASTALDI, J. P. Elementos de economia política. São Paulo: Saraiva, 2005.

HOBSBAWM, E. J. A era dos impérios, 1875-1914. Rio de Janeiro: Paz e Terra, 2014a.

HOBSBAWM, E. J. A era das revoluções, 1789-1848. Rio de Janeiro: Paz e Terra, 2014b.

HOBSBAWM, E. J. A era do capital, 1848-1875. Rio de Janeiro: Paz e Terra, 2014c.
KARNAL, L. A formação da nação. In: KARNAL, L. et al. História dos Estados Unidos: das origens ao século XXI. São Paulo: Contexto, 2004. e-book.

KOSELLECK, R. Uma história dos conceitos: problema teóricos e práticos. Estudos Históricos, v. 5, n. 10, pp. 134-146, 1992.

KOSELLECK, R. Futuro passado: contribuição à semântica dos tempos históricos. Rio de Janeiro: Contraponto: Ed. PUC-Rio, 2006.

MAINGUENEAU, D. Discurso e análise do discurso. In: SIGNORINI, I. (Org.). [Re]discutir texto, gênero e discurso. São Paulo: Parábola, 2008. pp. $135-156$.

MATITZ, Q. R. S.; VIZEU, F. Construção e uso de conceitos em estudos organizacionais: por uma perspectiva social e histórica. Revista de Administração Pública, Rio de Janeiro, v. 46, n. 2, pp. 577-598, 2012.

MOURA, G. Hipergeneralizações: organizações são quase qualquer coisa em best-sellers de introdução à administração. Cadernos EBAPE.BR, Rio de Janeiro, v. 12, n. 1, pp. 62-85, 2014.

PERROW, C. Organizing America: wealth, power, and the origins of corporate capitalism. Princeton, NJ: Princeton University Press, 2002.

PIERANTI, O. P. A metodologia historiográfica na pesquisa em administração: uma discussão acerca de princípios e de sua aplicabilidade no Brasil contemporâneo. Cadernos EBAPE.BR, Rio de Janeiro, v. 6, n. 1, pp. 1-12, 2008

RAMOS, A. A teoria administrativa e a utilização inadequada de conceitos. Revista de Administração Pública, Rio de Janeiro, v. 17, n. 1, pp. $66-76,1983$

SEIFERT, R. E.; VIZEU, F. Crescimento organizacional: uma ideologia gerencial? Revista de Administração Contemporânea, v. 19, n. 1, pp. 127-141, 2015

SMITH, A. A riqueza das nações. São Paulo: Nova Cultural, 1976.

TRAGTENBERG, M. Administração, poder e ideologia. São Paulo: Ed. Unesp, 2005.

VAN DIJK, T. A. La noticia como discurso: compreensión, estrutura y producción de la información. Madri: Síntesis, 1990.

VAN DIJK, T. A. Ideologia: una aproximación multidisciplinaria. Barcelona: Gedisa, 2006

VAN DIJK, T. A. Discurso e poder. São Paulo: Contexto, 2012.

VAN DIJK, T. A. Ideologia. Letras de Hoje, v. 50, s53-s61, 2015. Suplemento.

VIZEU, F. Potencialidades da análise histórica nos estudos organizacionais brasileiros. Revista de Administração de Empresas, v. 50, n. 1 , pp. $36-46,2010$

WEBER, M. História geral da economia. São Paulo: Centauro, 2006.

WEBER, M. A ética protestante e o espírito do capitalismo. São Paulo: Martin Claret, 2009.

WHITE, R. Railroaded: the transcontinentals and the making of modern America. New York: W. W. Norton, 2012.

WOLMAR, C. The great railway revolution. London: Atlantic Books, 2012a.

WOLMAR, C. Engines of war: how wars were won \& lost on the railways. London: Atlantic, 2012b. 
Alexandre Hochmann Béhar

ORCID: https://orcid.org/0000-0002-8354-7866

Ph.D. in Administration; Basic, Technical and Technological Education (EBTT) Professor of Business at Federal Institute of Education, Science and Technology of Pernambuco (IFPE), Paulista Campus, Paulista - Pernambuco, Brazil. E-mail: alexandre.behar@paulista.ifpe.edu.br

Ph.D. in Education; Assistant Professor in the Department of Administrative Sciences at Federal University of Pernambuco (UFPE), Recife Pernambuco, Brazil. E-mail: marcosggfeitosa@gmail.com 